\title{
VALPROATE IS AN ANTI-ANDROGEN AND ANTI-PROGESTIN
}

\section{Kristine CY McGrath ${ }^{1}$, Alison K Death ${ }^{2,3}$, David J Handelsman ${ }^{2,4}$}

1. Discipline of Medicine, University of Sydney, NSW, Australia

2. University of Sydney, NSW, Australia

3. Heart Research Institute, Camperdown, NSW, Australia

4. ANZAC Research Institute, Concord Hospital, NSW, Australia

Running Title: Valproate is an anti-androgen and anti-progestin

All correspondence to:

Dr Alison Death

Heart Research Institute

145 Missenden Road

Camperdown, NSW, 2050 Australia

Phone: +6129550 3560

Fax: +61295503302

Email:deatha@hri.org.au

Total Words 4401

Abstract 248

Introduction 418

Discussion 945

Text pages including references and figure legends 15

Tables 0

Figures 4

References: 50 


\section{ABSTRACT}

Anticonvulsant treatment is associated with a high prevalence of reproductive dysfunction compared with age-matched non-epileptics. The contributions from reproductive endocrine effects of anticonvulsant drugs relative to other factors including the convulsions, underlying neurological disease, and psychosocial concomitants remains difficult to disentangle. We examined the widely used anticonvulsants valproate (VPA) and carbamazepine (CBZ) for steroidal bioactivity using yeast-based steroid receptor-reporter system. In vitro bioassays for reproductive steroids were established by stably transforming yeast cells with human CDNA for androgen receptor $(\mathrm{AR})$, progesterone receptor $\mathrm{A}(\mathrm{PR})$ or estrogen receptor $\alpha(\mathrm{ER})$ together with a reporter plasmid containing a B-galactosidase gene under transcriptional control of an androgen (ARE), progestin (PRE) or estrogen (ERE) reporter element. Bioassays were performed by culturing yeast in the absence (agonist bioassay) or presence (antagonist bioassay) of cognate ligands $(5 \mathrm{nmol} / \mathrm{L}$ testosterone for $A R, 1.6 \mathrm{nmol} / \mathrm{L}$ progesterone for $\mathrm{PR}$ and $5 \mathrm{nmol}$ estradiol for $\mathrm{ER}$ ) for 4 (PR) or 16 (AR, ER) hours using B-galactosidase activity in yeast cell lysates as the end-point. VPA showed dose-dependent inhibition of progesterone-induced PR- and testosterone-induced AR activity. VPA had no ER antagonist bioactivity nor any AR, PR or ER agonist bioactivity. CBZ had no significant agonist or antagonist AR, PR or ER bioactivity. We conclude that VPA is a non-steroidal antagonist for human AR and PR but not ER. VPA's androgen and progesterone antagonism at concentrations much lower than therapeutic blood levels $(350-700 \mu \mathrm{M})$ seems likely to contribute to the frequency of reproductive endocrine disturbances among patients treated with VPA. 


\section{INTRODUCTION}

Epilepsy is associated with a high prevalence of reproductive dysfunction in men (1) and women $(2,3)$. These disorders include subfertility, anovulation, menstrual disturbance, hyperandrogenism, lowered effectiveness of oral contraception, adverse pregnancy outcomes in women $(2,3)$ and sexual dysfunction, androgen deficiency symptoms, testicular atrophy, impaired spermatogenesis and subfertility in men (1) compared with age-matched non-epileptics. These effects appear to be multifactorial with reproductive endocrine effects due to anti-convulsant drugs and epilepsy itself as well as psychosocial factors all contributing to the high prevalence of reproductive disorders.

Among anticonvulsants, carbamazepine (CBZ) and valproate (VPA) are among the two most widely used. In epileptic patients, increased blood steroid hormone binding globulin (SHBG) concentrations are the most consistent change observed in reproductive endocrine parameters with anticonvulsant drugs $(4,5)$. Increased SHBG reduces metabolic clearance of testosterone (6) and could thereby impair endogenous sex steroid action. It is unlikely, however, this is sufficient to explain the diversity of reproductive disorders of patients on long-term anticonvulsants (1-3) and other pathogenic mechanisms are likely to be involved.

The possibility that CBZ and VPA may have reproductive endocrine effects due to interaction of these drugs with the sex hormone receptors, androgen receptor (AR), estrogen receptor (ER) and progesterone receptor (PR) has not been evaluated. All three receptors belong to a large superfamily of nuclear hormone receptors that share a well-conserved DNA-binding domain (DBD), a structurally conserved ligand-binding domain (LBD) and an N-terminal domain with no homology between the different receptors (7). After ligand binding, the receptor dimerizes and binds to hormone response elements located within the promoters of hormone-responsive genes to act as a ligand-activated transcription factor. Drugs can interfere with this receptormediated process by many potential mechanisms including altering blood hormone levels (via changes in synthesis, distribution, metabolism or clearance), modifying steroid receptor expression levels, directly binding to the receptor to mimic or block steroid function or interacting with post-receptor co-regulator proteins. So far only the first possibility has been considered in any detail. We therefore utilised a system 
whereby each of the mammalian sex steroid receptors are stably introduced into the yeast strain Saccharomyces cerevisae to function as steroid-dependent transcription activators. This yeast reporter assays can then serve as useful tools for studying mammalian steroid receptor function. In the present study, therefore we used yeastbased $A R, P R$ or $E R$ in-vitro bioassays to investigate potential interactions of $C B Z$ or VPA with these sex steroid hormone receptors. We show that VPA, but not CBZ, antagonizes both $A R$ and $P R$ action without effects on ER. 


\section{MATERIALS AND METHODS}

\section{Materials}

Hormones, valproate and carbamazapine were obtained from Sigma-Aldrich (Castle Hill, NSW, Australia) and dissolved in ethanol for stock concentrations.

\section{Plasmids and Reporter Gene Constructs}

The full-length hPR cDNA plasmid and the PRE-B-galactosidase reporter plasmid were kindly provided by Professor DP McDonnell. Yeast strain YPH500 (MATa, ura352, lys2-801, ade2-101, trp1- $\Delta 63$, his3- $\Delta 200$, leu2- $\Delta 1$ ) was co-transformed with both plasmids by standard alkali-transformation (Alkali cation yeast transformation kit, BIO101 systems, Qbiogene Inc., Carlsbad, CA, USA). Co-transformant yeast strains were selected by tryptophan and uracil auxotrophy. Yeast strains (1) YPH500 transformed with YEpE22 and YRpE2 and (2) YPH500 transformed with YEpAR and YPpG2 were also kindly provided by Professor DP McDonnell.

\section{Yeast culture}

Yeast transformants were grown overnight at $30^{\circ} \mathrm{C}$ with vigorous orbital shaking at $300 \mathrm{rpm}$ in CSM-leu-ura (ER,AR BIO101) or CSM-trp-ura (PR, BIO101). Following overnight culture, the yeast culture was subcultured in fresh medium and allowed to grow until early-mid-log phase (OD600nm 1.0).

\section{Estrogen, progesterone and androgen receptor assays}

For $A R$ and ER bioassays, yeast from early-mid-log phase growth were diluted (to OD600=1.0) in selective medium (CSM-leu-ura) plus $100 \mu \mathrm{M} \mathrm{CuSO}_{4}$ to induce receptor production. For the PR bioassay, yeast were diluted (to $\mathrm{OD} 600=0.7$ ) in selective medium (CSM-trp-ura). Diluted yeast were aliquoted into 24-well culture plates $(500 \mu \mathrm{l} /$ well) and $5 \mu \mathrm{l}$ doses of steroid or drug were added. For antagonism experiments, $5 \mu \mathrm{l}$ of testosterone $\left(5 \times 10^{-9} \mathrm{M}\right)$ or progesterone $\left(1.6 \times 10^{-9} \mathrm{M}\right)$ or estradiol $(5 \times 10-9 \mathrm{M})$ and $5 \mu \mathrm{l}$ of valproate or carbamazapine $\left(1 \times 10^{-7} \mathrm{M}\right)$ were added. Each assay included testosterone (AR), progesterone (PR) or estradiol (ER) standard curve as well as a vehicle $\left(0.1 \%\right.$ ethanol) control. Multiwell plates were incubated at $30^{\circ} \mathrm{C}$ with shaking for either overnight (AR \& ER) or $4 \mathrm{hr}(\mathrm{PR})$. After incubation, the yeast culture samples were washed in assay buffer, lysed and extract assayed for $\beta$ - 
galactosidase. Dose-responses were fitted to a 4 parameter sigmoid curve using nonlinear regression option in Sigmaplot version 8.

\section{B-galactosidase assay}

After incubation, the yeast culture samples were transferred to $1.7 \mathrm{ml}$ microcentrifuge tubes, centrifuged at 3,000 rpm, and the cells resuspended in $250 \mu \mathrm{l}$ of assay buffer (60 mM Na $2 \mathrm{HPO}_{4}, 40 \mathrm{mM} \mathrm{NaH} \mathrm{PO}_{4}, 10 \mathrm{mM} \mathrm{KCl}, 1 \mathrm{mM} \mathrm{MgSO}$,). Cells were incubated on ice for $15 \mathrm{mins}$ and then lysed by vortexing in the presence of $4.5 \mu \mathrm{l}$ $0.1 \%$ SDS and $9 \mu \mathrm{l}$ chloroform. Lysate was then warmed to $30^{\circ} \mathrm{C}$ ( 5 mins) before 30 $\mu \mathrm{l}$ ONPG $(4 \mathrm{mg} / \mathrm{ml})$ added and incubated at $30^{\circ} \mathrm{C}$ until formation of yellow color. Reaction was stopped with addition of $75 \mu$ sodium carbonate $(1 \mathrm{M})$. The exact time was recorded. The yellow color (ONPG cleavage) was measured at $\mathrm{OD}_{420}$ and $\mathrm{OD}_{550}$. B-galactosidase activity was determined by $\left[1000^{*} \mathrm{OD}_{420^{-}}\right.$ $\left(\left(1.75^{\star} \mathrm{OD}_{550}\right) /\left(\right.\right.$ time $^{*}$ volume $\left.\left.\left.^{\star} \mathrm{OD}_{600}\right)\right)\right]$

\section{Statistical analysis}

Results of the experimental studies are reported as mean ${ }_{ \pm}$SE compared to controls. Unpaired Student's t-tests were used to determine the significance of changes between groups. A value of $\mathrm{P}<0.05$ was regarded as significant. 


\section{RESULTS}

The dose-response characteristics of the yeast PR, AR and ER bioassays were established by measuring the response to the receptor's cognate ligands progesterone, testosterone and estradiol, respectively, over the steroid concentration range from $10^{-6} \mathrm{M}$ to $10^{-16} \mathrm{M}$ (Figure 1).

The potential agonist activity of carbamazepine and valproate were evaluated at 10 $\mu \mathrm{M}$ concentration. Neither drug produced nonspecific yeast cell toxicity at this dose. Neither carbamazepine nor valproate displayed agonist activity for any of the 3 steroid hormone receptors (Figure 2).

The antagonist activity of carbamazepine and valproate were evaluated at $10 \mu \mathrm{M}$ concentration in the presence of mid-range doses $\left(\sim E_{50}\right)$ of the appropriate hormone $(5 \mathrm{nmol} / \mathrm{L}$ testosterone, $1.6 \mathrm{nmol} / \mathrm{L}$ progesterone, $5 \mathrm{nmol} / \mathrm{L}$ estradiol). Maximal effects of valproate $(100 \mu \mathrm{M})$ achieved blockade of $A R$ activity to $40 \%$ - and PR activity to $\sim 22 \%$ of $E C_{50}$-induced PR activity. Carbamazepine showed no antagonist effects. Neither valproate or carbamazepine demonstrated antagonism at the ER (Figure 3).

We further characterized the antagonist activity of valproate by determining the effects of lower concentrations of valproate on testosterone-, dihydrotestosterone- and progesterone- inducing activity (Figure 4). VPA demonstrated a dose-dependent blockade of AR activity with first significant effect at $30 \mu \mathrm{M}$ for both testosterone and dihydrotestosterone. VPA also showed dose-dependent inhibition of progesteroneinduced PR activity with first detectable effects at $10 \mu \mathrm{M}$. 


\section{DISCUSSION}

Reproductive dysfunction including subfertility (8-10) and disruption of reproductive endocrine function including menstrual disturbances and anovulation, hyperandrogenism and polycystic ovary (PCO)-like syndrome in women (11-13) and sexual dysfunction and androgen deficiency in men (1) are common in patients with epilepsy. The role of anticonvulsant drugs in these diverse reproductive disorders remains unclear as most clinical studies have been observational and relatively small. Nevertheless, prospective studies demonstrate endocrine effects of antiepileptic drugs the most consistent being increased blood SHBG concentration $(4,5,14,15)$, although the mechanism remains unknown. Other endocrine changes are not readily explained solely by increased blood SHBG concentrations.

Valproate is among the most frequently prescribed anticonvulsant drugs used by more than 2 million people daily (16). Its role in the reproductive endocrine disturbances frequently present in men and women with epilepsy is controversial $(1,11,13,16)$. As well as a broad spectrum of antiepileptic drug, valproate is also prescribed as a mood stabiliser for bipolar disorders, for neuropathic pain including headache and for migraine prophylaxis $(17,18)$. The present study shows that VPA, at concentrations much lower than therapeutic blood levels, blocks AR and PR, but not ER, action in an in-vitro bioassay. By contrast, carbamazepine had no detectable agonist or antagonist steroidal bioactivity and neither VPA nor CBZ had any sex steroid agonist activity in vitro. These findings indicate that valproate may produce clinical effects as an antiandrogen and anti-progestin when used as an anticonvulsant.

The low fertility of women with epilepsy $(9,10,19)$ has many contributing factors including social as well as biological factors. The strong PR antagonism by valproate, detectable at $10 \mu \mathrm{M}$ and nearly complete at $100 \mu \mathrm{M}$ compared with blood therapeutic concentrations of $350-700 \mu \mathrm{M}$, suggests some biological effects in women may be at least partly due to impaired PR-mediated progesterone action on reproductive tissues notably the uterus, breast and ovary. The anti-progestin effects of valproate may be a previously unrecognised factor contributing to the low fertility of women with epilepsy, notably to their otherwise unexplained higher rates of apparent miscarriage (8). In addition, anti-progestin effects may contribute to the higher frequency of anovulation among valproate-treated women with epilepsy (20) as mice null for PRA, but not PRB, 
fail to ovulate $(21,22)$. Further studies are required to clarify the contribution and mechanism of valproate in lowering reproductive potential of women with epilepsy or bipolar mood disorder. Apart from progesterone's role as a universal precursor on the steroidogenic pathway, there is no known role of progesterone mediated via a progesterone receptor in men so there are no known or likely male reproductive health effects of the anti-progestin effects of valproate.

The anti-androgenic effects of valproate are most likely to be manifest in men with epilepsy. These effects might contribute to the delayed puberty (23), impaired reproductive function and androgenic effects (1) reported in males with epilepsy. The most characteristic biochemical effects expected for a drug with pure anti-androgen properties would be increases in blood testosterone and LH (and to a lesser extent FSH) concentrations (24) comparable with the findings in androgen insensitivity due to an inactivated androgen receptor (25) or treatment with non-steroidal anti-androgen $(26,27)$. Such findings are reported in hormonal studies of men with epilepsy with control non-epileptic populations $(5,28-30)$. The alternative interpretation of such antiandrogenic effects is attributing them to increased blood SHBG concentrations, and consequently lowered "free" or biologically active testosterone, remains speculative.

The more prominent effects of valproate compared with carbamazepine is consistent with the clinical evidence that valproate treatment is associated with greater disruption of reproductive endocrine function than other anticonvulsant drugs $(11,15,31)$. Similarly, valproate treatment for other conditions such as bipolar mood disorders and migraine is also associated with similar disruption of reproductive endocrine function to a greater extent than other treatments $(32,33)$. Nevertheless, the available clinical studies are limited in explanatory power due to their mostly observational design and small sample size. Previous mechanistic studies have shown valproate has endocrine effects such as activation of PPAR (34), demethylation of DNA in an in vitro cell model (35), modulation of GABA-ergic neuronal input to the hypothalamus $(36,37)$ and a range of metabolic effects notably increasing blood leptin and insulin, but decreasing IGFBP1, levels (11, 32, 38, 39).

Whether the anti-androgenic effects of valproate have any clinical significance in women, where blood androgens are normally at levels equivalent to castrate men or children remains doubtful. At the level of the ovarian follicle these effects may 
stimulate ovarian androgen synthesis (38) as well as inhibiting follicular aromatization $(40,41)$. In normal non-epileptic rats, long-term VPA treatment induced endocrine changes and increased the number of ovarian follicular cysts (42). Similarly, in male rats high doses of valproate retards fertility, inhibit fertility, testicular weight and spermatogenesis as well as epididymal and prostate weight in rodents and larger mammals (43-48). While these changes are likely to be due to the lowered blood testosterone concentrations, valproate does not directly inhibit androgen biosynthesis $(49,50)$. The findings of increased LH and FSH in some (42) but not all (46) studies is consistent with valproate's anti-androgen action in an in-vitro bioassay.

In conclusion, we have shown using a yeast-based in-vitro bioassay for steroid hormones that VPA, a commonly used anticonvulsant for treatment of epilepsy and bipolar disorder, is an antiandrogen and antiprogestin but has no antiestrogen effects. These effects of VPA are evident at concentrations well below therapeutic blood concentrations of valproate when used to treat epilepsy or bipolar mood disorder. By contrast, carbemazapine had no sex steroid hormone receptor bioactivity. These findings suggest a new reproductive endocrine mechanism for valproate in the frequent reproductive dysfunction reported in valproate treated patients.

\section{Acknowledgments}

We are grateful to Professor Donald P McDonnell for the gift of plasmids YEphPR-B, YRpG2 and transformed yeast strains YPH500 transformed with YEpE22 and YRpE2 and YPH500 transformed with YEpAR and YPpG2. 


\section{Figure Legends}

Figure 1: Yeast bioassay for $A R, P R$ and ER activity. (A) Dose response curve for testosterone induced AR activity. Testosterone (dose range $10^{-6}$ to $10^{-16} \mathrm{M}$ ) was added to yeast cultures for an incubation period of 24 hours before the culture media assayed for $\beta$-galactosidase activity. Values represent the mean \pm SE of 6 separate experiments. (B) Dose response curve for progesterone induced PRA activity. Progesterone (dose range $10^{-6}$ to $10^{-16} \mathrm{M}$ ) was added to yeast cultures for an incubation period of 4 hours before culture media assayed for $\beta$-galactosidase activity. Values represent the mean \pm SE for 6 separate experiments. (C) Dose response curve for estradiol induced $\mathrm{ER} \alpha$ activity. Estradiol (dose range $10^{-6}$ to $10^{-16} \mathrm{M}$ ) was added to yeast cultures for an incubation period of 24 hours before culture media assayed for $\beta$-galactosidase activity. Values represent the mean \pm SE of 3 separate experiments. All curves are presented as the \% of maximal $\beta$-galactosidase activity.

Figure 2: The effects of $\mathrm{CBZ}$ and VPA on androgen, progesterone and estrogen bioassays. (A) AR agonist activity of $C B Z$ and VPA relative to $E C_{50}$ testosterone dose $\left(5 \times 10^{-9} \mathrm{M}\right)$. Yeast cultures were treated with either $10 \times 10^{-6} \mathrm{M} \mathrm{CBZ}$ or VPA or $5 \mathrm{X}$ $10^{-9} \mathrm{M}$ testosterone and incubated for 24 hours. Following incubation, $\beta$-galactosidase activity was assayed and values represent the mean \pm SE of 3 separate experiments. Values are expressed as \% of $5 \times 10^{-9} \mathrm{M}$ testosterone-induced $\beta$-galactosidase activity. (B) PR agonist activity of $C B Z$ and $V P A$ relative to $E_{50}$ dose of progesterone $\left(1.6 \times 10^{-9} \mathrm{M}\right)$. Yeast cultures were treated with either $10 \times 10^{-6} \mathrm{M} \mathrm{CBZ}$ or VPA or 1.6 $X 10^{-9} \mathrm{M}$ progesterone and incubated for 4 hours. Following incubation, $\beta$ galactosidase activity was assayed and values represent the mean \pm SE of 3 separate experiments. Values are expressed as \% of $1.6 \times 10^{-9} \mathrm{M}$ progesterone-induced $\beta$ galactosidase activity. (C) ER agonist activity of CBZ and VPA relative to $E_{50}$ dose of estradiol $\left(5 \times 10^{-9} \mathrm{M}\right)$. Yeast cultures were treated with either $10 \times 10^{-6} \mathrm{M} \mathrm{CBZ}$ or VPA or $5 \times 10^{-9} \mathrm{M}$ estradiol and incubated for 24 hours. Following incubation, $\beta$ galactosidase activity was assayed and values represent the mean \pm SE of 3 separate experiments. Values are expressed as \% of $5 \times 10^{-9} \mathrm{M}$ estradiol-induced $\beta$ galactosidase activity. 
Figure 3: VPA inhibitory action in androgen and progesterone, but not estrogen, bioassays. (A) VPA antagonism of testosterone-induced AR activity. Yeast cultures were incubated for 24 hours with $5 \times 10^{-9} \mathrm{M}$ testosterone in the presence of $10 \times 10^{-6}$ $\mathrm{M}$ valproate or $10 \times 10^{-6} \mathrm{M}$ carbamazepine. Values represent mean $\pm \mathrm{SE}$ of 4 separate experiments and are presented as $\%$ of $5 \times 10^{-9} \mathrm{M}$ testosterone-induced $\beta$ galactosidase activity. ${ }^{*} \mathrm{p}<0.05$. (B) VPA antagonism of progesterone-induced PR activity. Yeast cultures were incubated for 4 hours with $1.6 \times 10^{-9} \mathrm{M}$ progesterone in the presence of $10 \times 10^{-6} \mathrm{M}$ valproate or $10 \times 10^{-6} \mathrm{M}$ carbamazepine. Values represent mean \pm SE or 4 separate experiments and are presented as $\%$ of $1.6 \times 10^{-9}$ $M$ progesterone-induced $\beta$-galactosidase activity. ${ }^{*} p<0.005$. (C) No antagonism of estradiol-induced ER activity by VPA or CBZ. Yeast cultures were incubated for 24 hours with $5 \times 10^{-9} \mathrm{M}$ estradiol in the presence of $10 \times 10^{-6} \mathrm{M}$ valproate or $10 \times 10^{-6} \mathrm{M}$ carbamazepine. Values represent mean \pm SE or 4 separate experiments and are presented as $\%$ of $5 \times 10^{-9} \mathrm{M}$ estradiol-induced $\beta$-galactosidase activity.

Figure 4: Dose-dependent inhibition by increasing concentrations of valproate of progesterone $(\bullet)$, testosterone $(\boldsymbol{\square})$ or dihydrotestosterone $(\boldsymbol{\Delta})$ stimulated yeast cells. Yeast were cultured in the presence of $5 \times 10^{-9} \mathrm{M}$ testosterone or dihydrotesterone or $1.6 \times 10^{-9} \mathrm{M}$ progesterone together with $1-10 \times 10^{-6} \mathrm{M}$ valproate. Values represent mean \pm SE from 3 separate experiments and are presented as \% of maximal $\beta$ galactosidase activity. 
1. Herzog AG (2002) Altered reproductive endocrine regulation in men with epilepsy: implications for reproductive function and seizures. Ann Neurol 51:539-42.

2. Yerby MS (2000) Special considerations for women with epilepsy. Pharmacotherapy 20:159S-170S.

3. Bauer J, Isojarvi JI, Herzog AG, Reuber M, Polson D, Tauboll E, Genton P, van der Ven H, Roesing B, Luef GJ, Galimberti CA, van Parys J, Flugel D, Bergmann A, Elger CE (2002) Reproductive dysfunction in women with epilepsy: recommendations for evaluation and management. J Neurol Neurosurg Psychiatry 73:121-5.

4. Rattya J, Pakarinen AJ, Knip M, Repo-Outakoski M, Myllyla VV, Isojarvi JI (2001) Early hormonal changes during valproate or carbamazepine treatment: a 3-month study. Neurology 57:440-4.

5. Rattya J, Turkka J, Pakarinen AJ, Knip M, Kotila MA, Lukkarinen O, Myllyla VV, Isojarvi JI (2001) Reproductive effects of valproate, carbamazepine, and oxcarbazepine in men with epilepsy. Neurology 56:31-6.

6. Petra P, Stanczyk FZ, Namkung PC, Fritz MA, Novy ML (1985) Direct effect of sexsteroid binding protein (SBP) of plasma on the metabolic clearance rate of testosterone in the rhesus macaque. J Steroid Biochem Mol Biol 22:739-746.

7. Beato M, Klug J (2000) Steroid hormone receptors: an update. Hum Reprod Update 6:225-36.

8. Schupf N, Ottman R (1997) Reproduction among individuals with idiopathic/cryptogenic epilepsy: risk factors for spontaneous abortion. Epilepsia 38:824-9.

9. Schupf N, Ottman R (1996) Reproduction among individuals with idiopathic/cryptogenic epilepsy: risk factors for reduced fertility in marriage. Epilepsia 37:833-40.

10. Schupf N, Ottman R (1994) Likelihood of pregnancy in individuals with idiopathic/cryptogenic epilepsy: social and biologic influences. Epilepsia 35:750-6.

11. Isojarvi Jl, Laatikainen TJ, Pakarinen AJ, Juntunen KT, Myllyla VV (1993) Polycystic ovaries and hyperandrogenism in women taking valproate for epilepsy. $N$ Engl J Med 329:1383-8.

12. Isojarvi JI (2003) Reproductive dysfunction in women with epilepsy. Neurology 61:S27-34.

13. Morrell MJ (2003) Reproductive and metabolic disorders in women with epilepsy. Epilepsia 44 Supp/ 4:11-20.

14. Isojarvi JI, Laatikainen TJ, Pakarinen AJ, Juntunen KT, Myllyla VV (1995) Menstrual disorders in women with epilepsy receiving carbamazepine. Epilepsia 36:676-81.

15. Isojarvi JI, Repo M, Pakarinen AJ, Lukkarinen O, Myllyla VV (1995) Carbamazepine, phenytoin, sex hormones, and sexual function in men with epilepsy. Epilepsia 36:366-70.

16. Genton P, Bauer J, Duncan S, Taylor AE, Balen AH, Eberle A, Pedersen B, SalasPuig X, Sauer MV (2001) On the association between valproate and polycystic ovary syndrome. Epilepsia 42:295-304.

17. Ross EL (2000) The evolving role of antiepileptic drugs in treating neuropathic pain. Neurology 55:S41-6; discussion S54-8.

18. Agostoni E, Frigerio R, Santoro P (2003) Antiepileptic drugs in the treatment of chronic headaches. Neurol Sci 24 Supp/ 2:S128-31.

19. Webber MP, Hauser WA, Ottman R, Annegers JF (1986) Fertility in persons with epilepsy: 1935-1974. Epilepsia 27:746-52.

20. Murialdo G, Galimberti CA, Magri F, Sampaolo P, Copello F, Gianelli MV, Gazzerro E, Rollero A, Deagatone C, Manni R, Ferrari E, Polleri A, Tartara A (1997) Menstrual cycle and ovary alterations in women with epilepsy on antiepileptic therapy. J Endocrinol Invest 20:519-26.

21. Lydon JP, DeMayo FJ, Conneely OM, O'Malley BW (1996) Reproductive phenotpes of the progesterone receptor null mutant mouse. J Steroid Biochem Mol Biol 56:67-77. 
22. Conneely OM, Mulac-Jericevic B, DeMayo F, Lydon JP, O'Malley BW (2002) Reproductive functions of progesterone receptors. Recent Prog Horm Res 57:339-55.

23. El-Khayat HA, Shatla HM, Ali GK, Abdulgani MO, Tomoum HY, Attya HA (2003) Physical and hormonal profile of male sexual development in epilepsy. Epilepsia 44:447-52.

24. Reid P, Kantoff P, Oh W (1999) Antiandrogens in prostate cancer. Invest New Drugs 17:271-84.

25. Quigley CA, DeBellis A, Marschke KB, El-Awady MK, Wilson EM, French FF (1995) Androgen receptor defects: historical, clinical and molecular perspectives. Endocr Rev 16:271-321.

26. Decensi A, Torrisi R, Fontana V, Marroni P, Padovani P, Guarneri D, Minuto F, Boccardo F (1993) Long-term endocrine effects of administration of either a nonsteroidal antiandrogen or a luteinizing hormone-releasing hormone agonist in men with prostate cancer. Acta Endocrinol (Copenh) 129:315-21.

27. Verhelst J, Denis L, Van Vliet P, Van Poppel H, Braeckman J, Van Cangh P, Mattelaer J, D'Hulster D, Mahler C (1994) Endocrine profiles during administration of the new non-steroidal anti-androgen Casodex in prostate cancer. Clin Endocrinol (Oxf) 41:525-30.

28. Toone BK, Wheeler M, Nanjee M, Fenwick P, Grant R (1983) Sex hormones, sexual activity and plasma anticonvulsant levels in male epileptics. J Neurol Neurosurg Psychiatry 46:824-826.

29. Macphee GJA, Larkin JG, Butler E, Beastall GH, Brodie MJ (1988) Circulating hormones and pituitary responsiveness in young epileptic men receiving long-term antiepileptic medication. Epilepsia 29:468-475.

30. Duncan S, Blacklaw J, Beastall GH, Brodie MJ (1999) Antiepileptic drug therapy and sexual function in men with epilepsy. Epilepsia 40:197-204.

31. Morrell MJ, Isojarvi J, Taylor AE, Dam M, Ayala R, Gomez G, O'Neill F, Tennis P, Messenheimer $\mathbf{J}$ (2003) Higher androgens and weight gain with valproate compared with lamotrigine for epilepsy. Epilepsy Res 54:189-99.

32. McIntyre RS, Mancini DA, McCann S, Srinivasan J, Kennedy SH (2003) Valproate, bipolar disorder and polycystic ovarian syndrome. Bipolar Disord 5:28-35.

33. Akdeniz F, Taneli F, Noyan A, Yuncu Z, Vahip S (2003) Valproate-associated reproductive and metabolic abnormalities: are epileptic women at greater risk than bipolar women? Prog Neuropsychopharmacol Biol Psychiatry 27:115-21.

34. Lampen A, Siehler S, Ellerbeck U, Gottlicher M, Nau H (1999) New molecular bioassays for the estimation of the teratogenic potency of valproic acid derivatives in vitro: activation of the peroxisomal proliferator-activated receptor (PPARdelta). Toxicol Appl Pharmacol 160:238-49.

35. Detich N, Bovenzi V, Szyf M (2003) Valproate induces replication-independent active DNA demethylation. J Biol Chem 278:27586-92.

36. Popovic V, Spremovic S (1995) The effect of sodium valproate on luteinizing hormone secretion in women with polycystic ovary disease. $J$ Endocrinol Invest 18:104-8.

37. Popovic V, Spremovic-Radjenovic S, Eric-Marinkovic J, Grossman A (1996) Effect of sodium valproate on luteinizing hormone secretion in pre- and postmenopausal women and its modulation by naloxone infusion. J Clin Endocrinol Metab 81:2520-4.

38. Vainionpaa LK, Rattya J, Knip M, Tapanainen JS, Pakarinen AJ, Lanning P, Tekay A, Myllyla VV, Isojarvi Jl (1999) Valproate-induced hyperandrogenism during pubertal maturation in girls with epilepsy. Ann Neurol 45:444-50.

39. Elmslie JL, Silverstone JT, Mann JI, Williams SM, Romans SE (2000) Prevalence of overweight and obesity in bipolar patients. J Clin Psychiatry 61:179-84.

40. Tauboll E, Gregoraszczuk EL, Kolodziej A, Kajta M, Ropstad E (2003) Valproate inhibits the conversion of testosterone to estradiol and acts as an apoptotic agent in growing porcine ovarian follicular cells. Epilepsia 44:1014-21.

41. Tauboll E, Wojtowicz AK, Ropstad E, Gregoraszczuk EL (2002) Valproate irreversibly alters steroid secretion patterns from porcine follicular cells in vitro. Reprod Toxicol 16:319-25. 
42. Sveberg Roste L, Tauboll E, Isojarvi JI, Pakarinen AJ, Huhtaniemi IT, Knip M, Gjerstad L (2002) Effects of chronic valproate treatment on reproductive endocrine hormones in female and male Wistar rats. Reprod Toxicol 16:767-73.

43. Cohn DF, Homonnai ZT, Paz GF (1982) The effect of anticonvulsant drugs on the development of male rats and their fertility. J Neurol Neurosurg Psychiatry 45:844-6.

44. Walker RM, Smith GS, Barsoum NJ, Macallum GE (1990) Preclinical toxicology of the anticonvulsant calcium valproate. Toxicology 63:137-55.

45. Snyder PJ, Badura LL (1995) Chronic administration of sodium valproic acid slows pubertal maturation in inbred DBA/2J mice: skeletal, histological, and endocrinological evidence. Epilepsy Res 20:203-11.

46. Soliman GA, Abla A, el M (1999) Effects of antiepileptic drugs carbamazepine and sodium valproate on fertility of male rats. Dtsch Tierarztl Wochenschr 106:110-3.

47. Nishimura T, Sakai M, Yonezawa H (2000) Effects of valproic acid on fertility and reproductive organs in male rats. J Toxicol Sci 25:85-93.

48. Sveberg Roste L, Tauboll E, Berner A, Berg KA, Aleksandersen M, Gjerstad L (2001) Morphological changes in the testis after long-term valproate treatment in male Wistar rats. Seizure 10:559-65.

49. Kuhn-Velten WN, Herzog AG, Muller MR (1990) Acute effects of anticonvulsant drugs on gonadotropin-stimulated and precursor-supported androgen production in the rat testis. Eur J Pharmacol 181:151-5

50. Ohnishi T, Ichikawa Y (1997) Direct inhibitions of the activities of steroidogenic cytochrome P-450 mono-oxygenase systems by anticonvulsants. $J$ Steroid Biochem Mol Biol 60:77-85. 
Progesterone dose-response curve

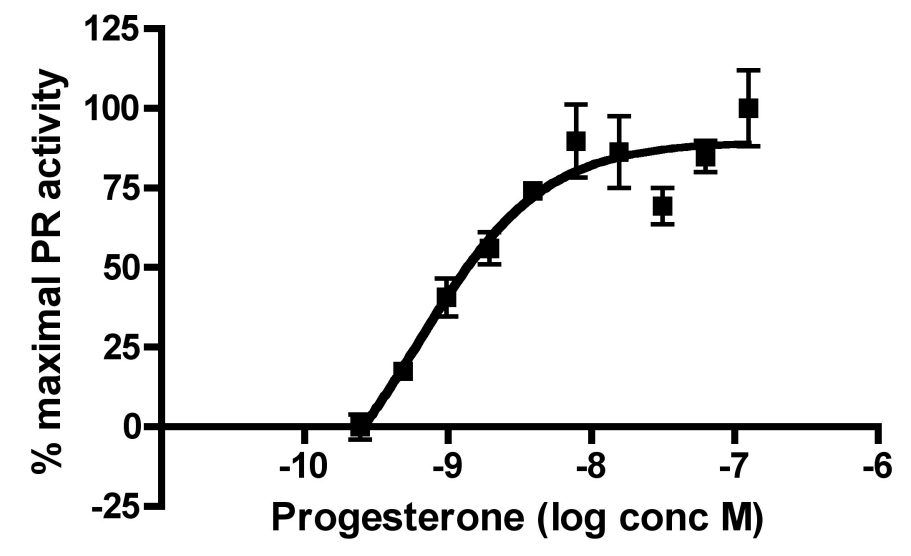

Tesosterone dose-response curve

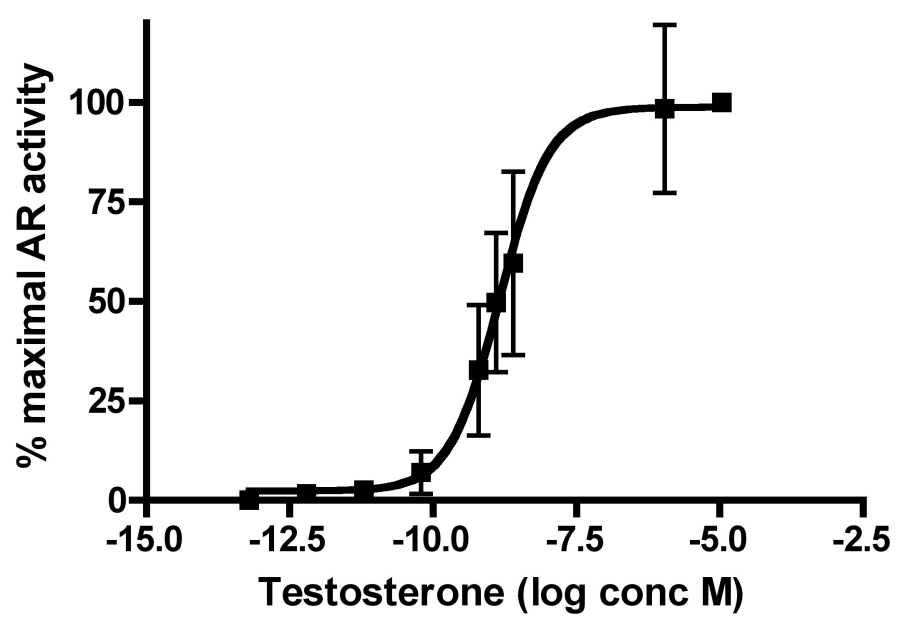

Estradiol dose-response curve

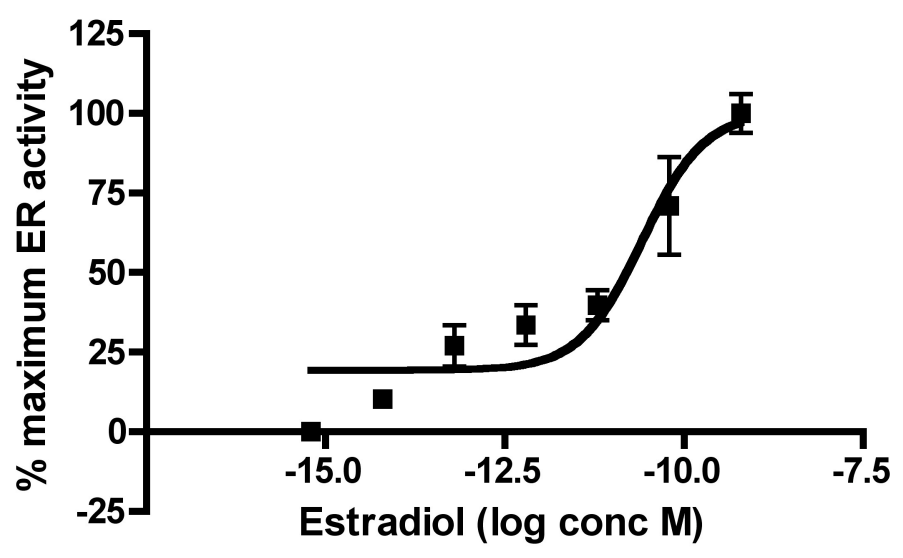


A

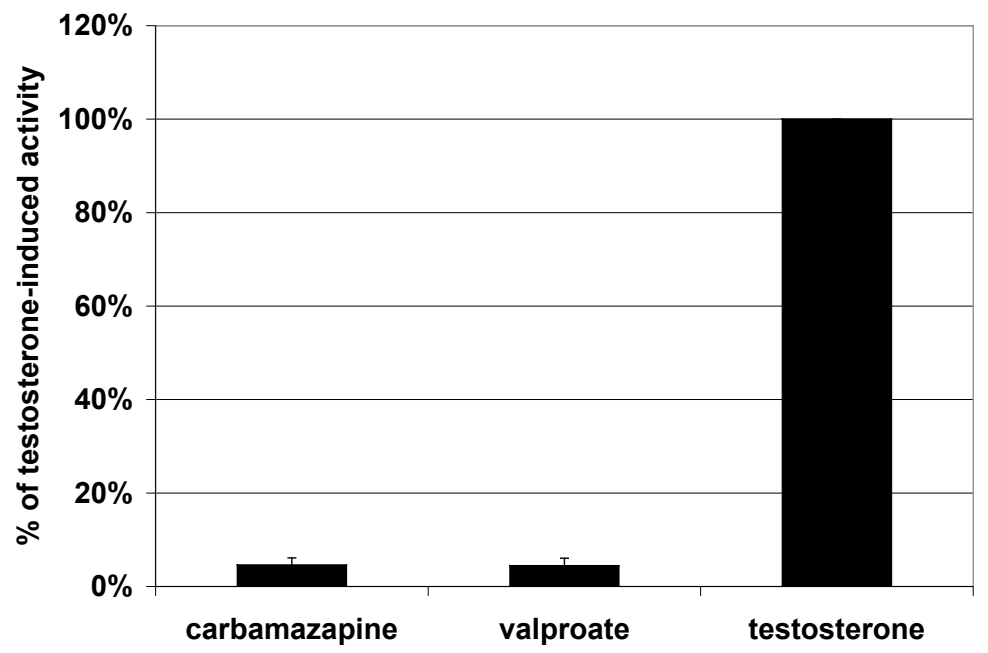

B

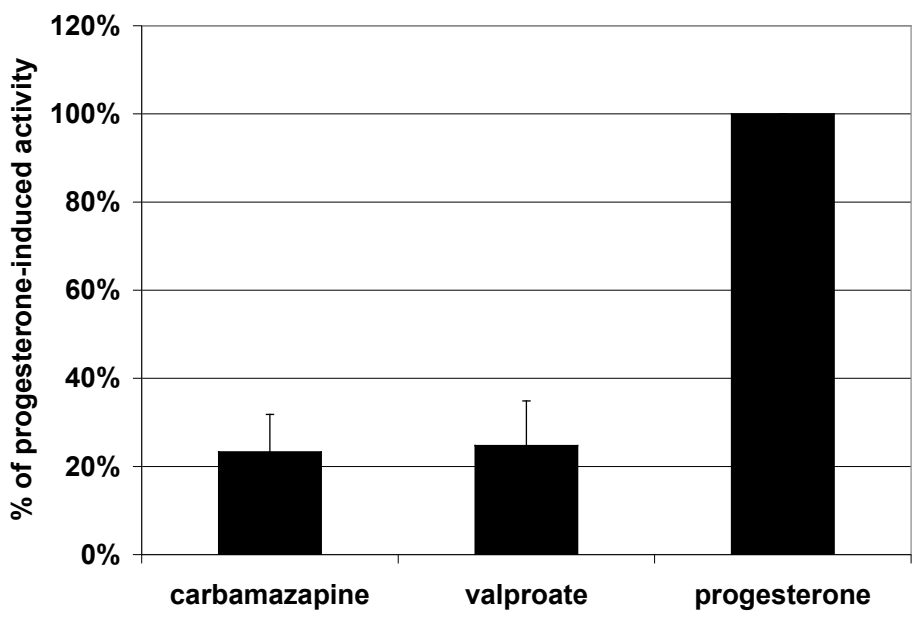

C

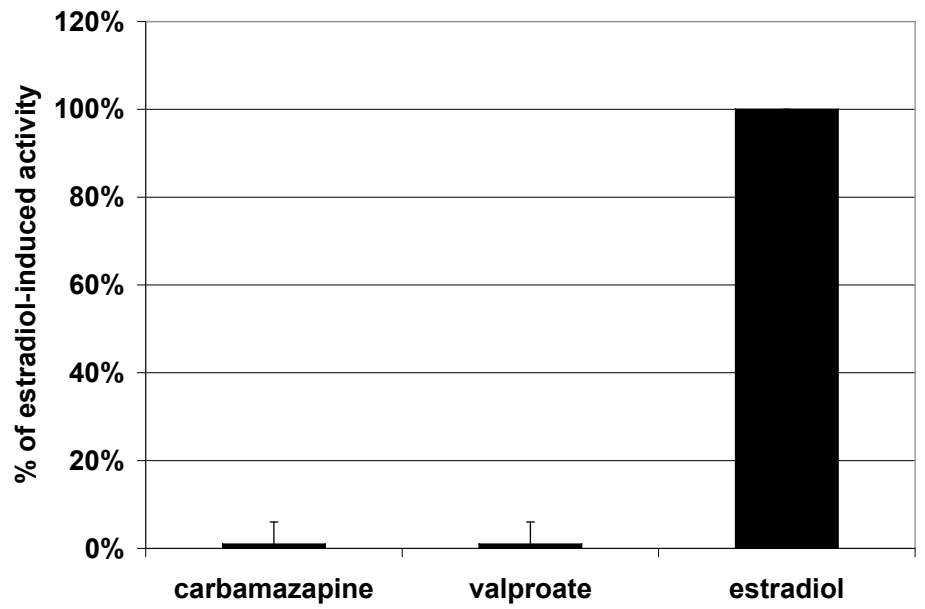


A

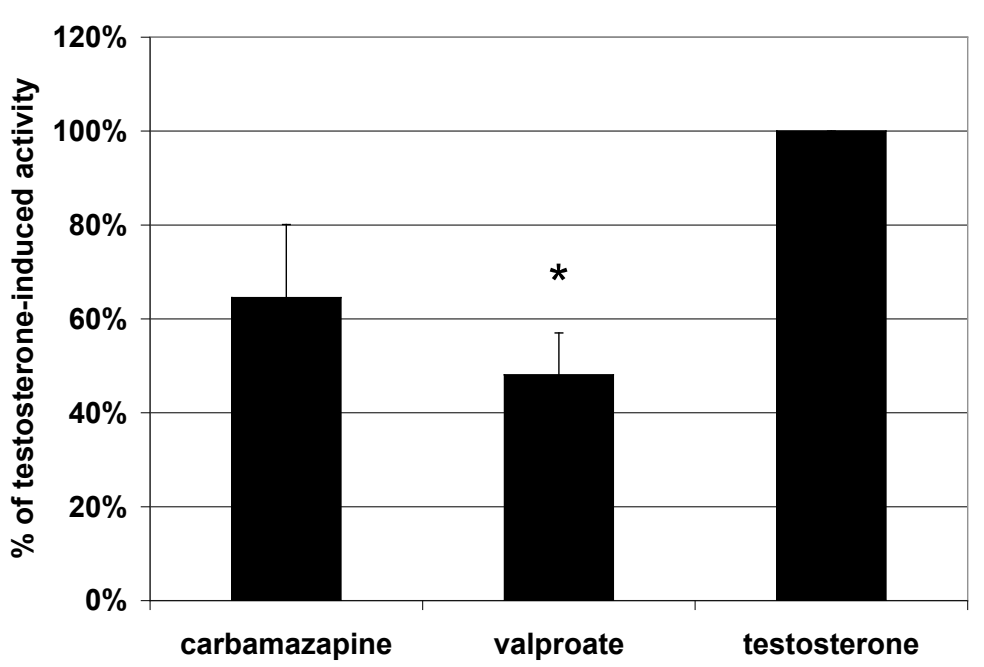

B

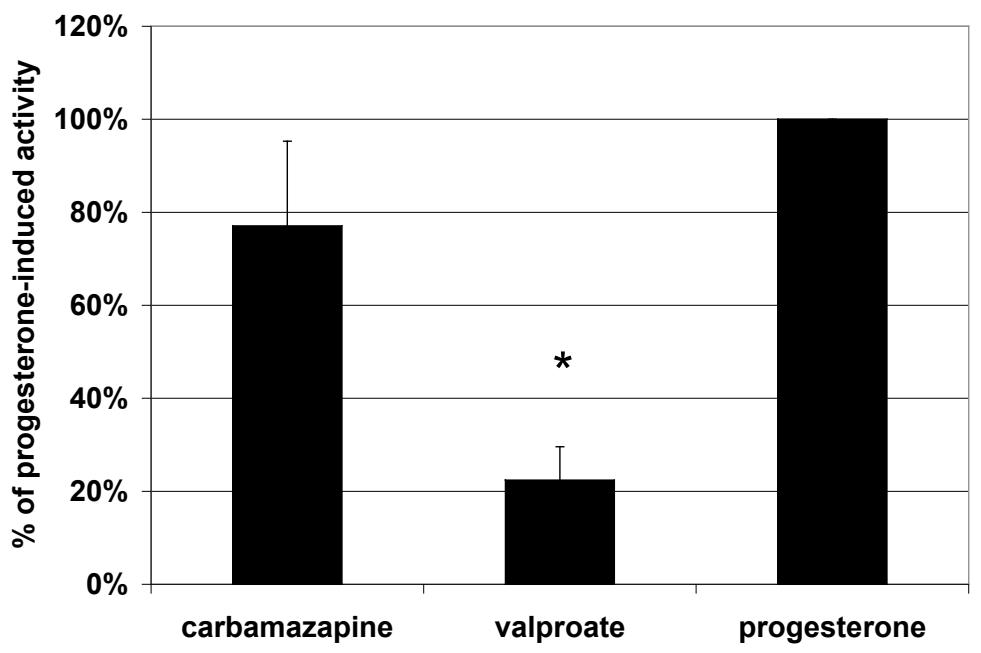

C




VPA dose response curves

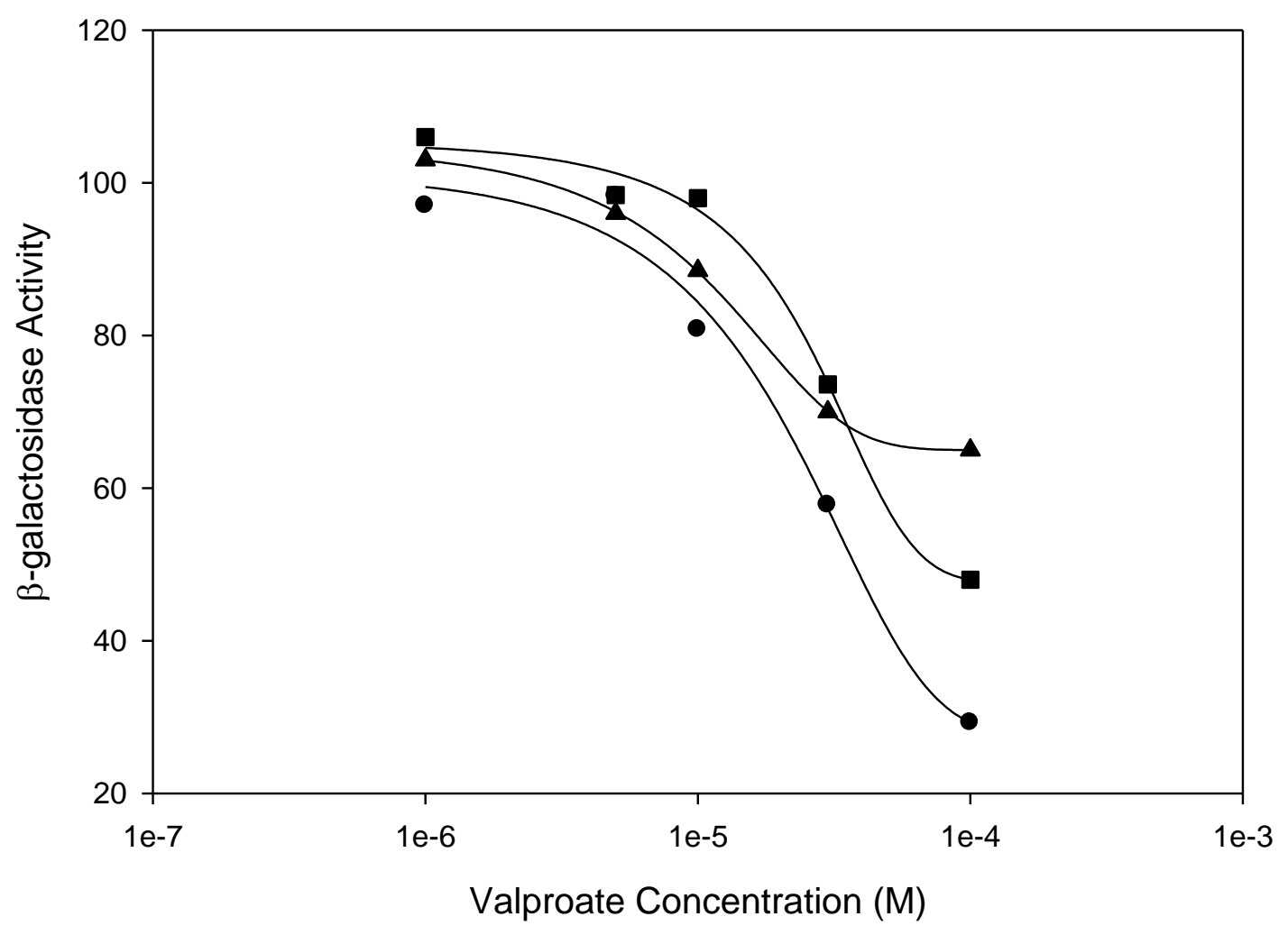

